\title{
Faktor Determinan Yang Berhubungan Dengan Kejadian Stunting Pada Balita Di Kabupaten Pesawaran Lampung
}

\author{
Determinant Factors Associated With Toddlers Stunting In Pesawaran \\ Lampung
}

\author{
Rita Sari $^{1}$, Apri Sulistianingsih ${ }^{1}$ \\ STIKes Muhammadiyah Pringsewu
}

\begin{abstract}
ABSTRAK
Status gizi Bayi Dibawah Lima Tahun (Balita) berpengaruh dengan kecerdasan anak. Menurut data Riset Kesehatan Dasar (Riskesdas) tahun 2013 didapatkan balita pendek sebesar 37,2\%. Prevalensi balita pendek di Provinsi Lampung yaitu 42,6\% dengan kondisi Kabupaten Pesawaran mencapai 50,81\%. Tujuan jangka panjang dari hasil penelitian ini adalah untuk mengetahui faktor determinan yang berhubungan dengan kejadian balita pendek.Desain penelitian ini adalah observasional analitik dengan pendekatan crossectional. Subjek dalam penelitian ini adalah pasangan ibu dan balita usai 2-5 tahun.Jumlah sampel pada penlitian ini adalah 385 pasangan ibu dan balita dari 12 Wilayah kerja Puskesmas di Pesawaran.Kriteria inklusi pada penelitian ini adalah: ibu dan balita di Wilayah Kerja Kabupaten Pesawaran, bersedia Mengikuti Penelitian. Kriteria eksklusi pada penelitian ini adalah balita yang memiliki cacat bawaan. Penelitian ini menggunakan uji chi square dan uji regresi logistik ganda. Hasil penelitian $46 \%$ berada pada kondisi stunting (pendek). Faktor Penghasilan, pola asuh dan pemberian makan berhubungan dengan kejadian balita stunting $(\rho<0,05)$. Penelitian ini menunjukkan faktor yang berhubungan empat faktor yang secara bersama-sama mempengaruhi stunting (pendek) di Kabupaten Pesawaran yaitu penghasilan, hygiene dan sanitasi, pola asuh dan pemberian makan. Faktor yang paling dominan adalah pola pemberian makan $(\mathrm{POR}=18,074)$. Risiko orang tua yang tidak melakukan pemberian makan dengan baik berisiko 18,0 kali pada balitanya menderita stunting bila dibandingkan dengan balita yang orang tuanya memiliki pola pemberian makan baik. Faktor pendapatan, pola asuh dan pemberian makan terhadap kejadian stunting di Kabupaten Pesawaran
\end{abstract}

Kata Kunci: Faktor, stunting, balita pendek

\begin{abstract}
The nutritional status of Infants Under Five Years (Toddlers) has an effect on children's intelligence. According to data of Basic Health Research (Riskesdas) in 2013 got a short toddler by 37.2\%. Prevalence of short toddler in Lampung Province is 42,6\% with Pesawaran regency condition reach 50,81\%. The long-term goal of this study is to determine the determinant factors associated with short toddler events. The design of this study was observational analytic with crossectional approach. Subjects in this study were mother and toddler couples after 2-5 years. The number of samples in this study were 385 mothers and under-five couples from 12 working areas of Puskesmas in Pesawaran. Inclusion criteria in this study were: mothers and toddlers in the Work Area of Pesawaran District, willing to follow the research. Exclusion criteria in this study are toddlers who have congenital defects. This study used chi square test and multiple logistic regression test. $46 \%$ of research results are in stunting condition (short). Factors Income, parenting and feeding associated with the incidence of toddlers stunting $(\rho<0.05)$. This study shows factors that relate to four factors that simultaneously influence stunting (short) in Pesawaran District ie income, hygiene and sanitation, parenting and feeding. The most dominant factor is the pattern of feeding (POR = 18,074). The risk of parents who do not do a good feed 18.0 times the risk of suffering from stunting when compared with toddlers whose parents have a good feeding pattern. Factors of income, parenting and feeding on stunting events in Pesawaran
\end{abstract}

Keywords: Factor, stunting, short toddler 


\section{PENDAHULUAN}

Malnutrisi pada ibu dan anak, dikenal dengan kurang gizi, kurus, kurang berat, dan defisiensi mikronutrien ${ }^{1}$.Semakin tinggi faktor risiko balita yang ada, semakin besar kemungkinan balita akan mengalami gangguan gizi². Malnutrisi memiliki efek buruk pada kelangsungan hidup, perkembangan sehat, tingkat penyakit akut dan kronis dan produktivitas ekonomi individu, masyarakat dan masyarakat. Malnutrisi menyebabkan efek jangka panjang sampai dewasa ${ }^{1}$. Anak-anak yang tidak memenuhi potensi penuh mereka untuk perkembangan fisik dan kognitif berisiko lebih besar terhadap kesehatan dan kemiskinan di masa dewasa ${ }^{3}$.

Menurut WHO (2014),sebanyak 23,8\% dariAnak-anak di bawah usia lima tahun mengalami stunting $\mathrm{WHO}^{4}$. Menurut data Riset Kesehatan Dasar (Riskesdas) tahun 2013 didapatkan Balita pendek sebesar 37,2\%. ${ }^{5}$ Kasus Balita pendek di Provinsi Lampung yaitu $42,6 \%$ dengan kondisi Kabupaten Pesawaran mencapai $50,81 \%^{5}$. Dari prevalensi total tersebut, Indonesia mengalami kasus balita pendek yang serius.

Gangguan gizi dapat disebabkan oleh perubahan pola makandan pengeluaran,

ekonomi,Demografis dan pola asuh. ${ }^{6}$ Sebuah studi kohort multi-nasional mengungkapkan sebuah asosiasi

Antara kemiskinan dan stunting. Kurang optimal Menyusui, dan makanan pendamping pelengkap tidak tepat, infeksi berulang dan kekurangan mikronutrien juga merupakan faktor determinant stunting. Kemiskinan menjadi kondisi permanen. hal Ini menyebabkan asupan makanan tidak memadai dan kondisi kesehatan yang buruk berakibat stunting. Tingkat keparahan infeksi Pada anak-anak dengan gizi buruk menghasilkan gangguan pertumbuhan ${ }^{4}$.

Berdasarkan tingginya prevalesi balita pendek (stunting) di kabupaten pesawaran yaitu 50,81\%. Angka ini jauh lebih tinggi dari cakupan nasional.Oleh sebab itu peneliti tertarik untuk mengetahui faktor-faktor yang berhubungan dengan kejadian balita pendek (stunting) di Kabupaten Pesawaran Lampung.Penelitian ini bertujuan untuk mengetahui faktorfaktor yang berpengaruh terhadap kejadian balita pendek (stunting)di Kabupaten Pesawaran.

\section{METODE}

Penelitian dengan desain studi cross sectional telah dilaksanakan pada bulan 
Maret- Mei 2017di 12 Puskesmas

Kabupaten Pesawaran Lampung.Populasi pada penelitian ini adalah balita yang berusia 2-5 tahun di 12 Wilayah Kerja Puskesmas Kabupaten Pesawaran. Seluruh populasi kemudian diminta untuk berpartisipasi dalam penelitian. Berdasarkan rumus perhitungan sampel pada penelitian didapatkan sebanyak 385sampel yang memenuhi kriteria inklusi dan eksklusi.Pasangan Ibu dan Balita kemudian menyetujui untuk mengikuti penelitian dan menandatangani lembar persetujuan penelitian untuk menjadi Subjek Penelitian. Kirteria inklusi pada penelitian ini adalah Ibu dan balita (2-5 tahun) yang berkunjung di posyandu di 12 wilayah kerja Puskesmas Kabupaten Pesawaran Lampung dan Ibu yang bersedia menjadi responden. Kriteria eksklusi pada penelitian ini adalah Balita yang cacat bawaan.

Pada penelitian ini tidak melalui rekomendasi dan uji etik dari komite etik. Namun demikian penelitian ini menjunjuk tinggi prinsip etika dalam penelitian berupa prinsip respec for person, justice dan beneficience and non maleficience.Intrumen pengumpulan data yang digunakan untuk mengukur riwayat penyakit, tingkat pendidikan ibu, penghasilan keluarga, hygine dan sanitasi, pola asuh, pemberian makan dan tinggi badan berdasarkan umur.Analisis data yang dilakukan meliputi analisis univariat karakteristik responden. Analisis bivariat digunakan uji chi-square. Analisis multivariat digunakan untuk melihat faktor yang paling berpengaruh terhadap kejadian stunting padabalita dengan menggunakan regresi logistik dengan pemodelan prediksi.

\section{HASIL}

1. Analisis Bivariat

Analisis ini digunakan untuk melihat hubungan kondisi infeksi , pendidikan orang tua, penghasilan, hygiene dan sanitasi, pemberian makan dengan status gizi balita di Kabupaten Pesawaran. Penelitian ini menggunakan analisis uji chi square dengan $\mathrm{Cl} 95 \%$ dan $\alpha=0,05$ dapat dilihat pada tabel berikut:

$$
\text { Berdasarkan Tabel } 1
$$

Berdasarkan status gizi didapatkan bahwa 54,0 adalah normal, sedangkan $46 \%$ berada pada kondisi stunting (pendek). Hasil analisis antarakondisi infeksi, pendidikan orang tua, penghasilan, hygiene dan sanitasi, pola asuh, pemberian makan dengan status gizi balita di Kabupaten Pesawaran, dapat dilihat bahwa: Hasil uji statistik chi square menunjukkan bahwa kondisi infeksi, pendidikan orang tua dan hygine dan sanitasi tidak berhubungan signidikan dengan 
kejadian stunting $(\rho>0,05)$. Pada

analisis faktor penghasilan, pola asuh

dan pola pemberian makan

berhubungan sigifikan meningkatkan

kejadian stunting $(\rho<0,05)$.

Tabel 1 Hubungan Kondisi Infeksi , Pendidikan Orang Tua, Penghasilan, Hygiene Dan Sanitasi, Pemberian Makan Dengan Status Gizi Balita Di Kabupaten Pesawaran

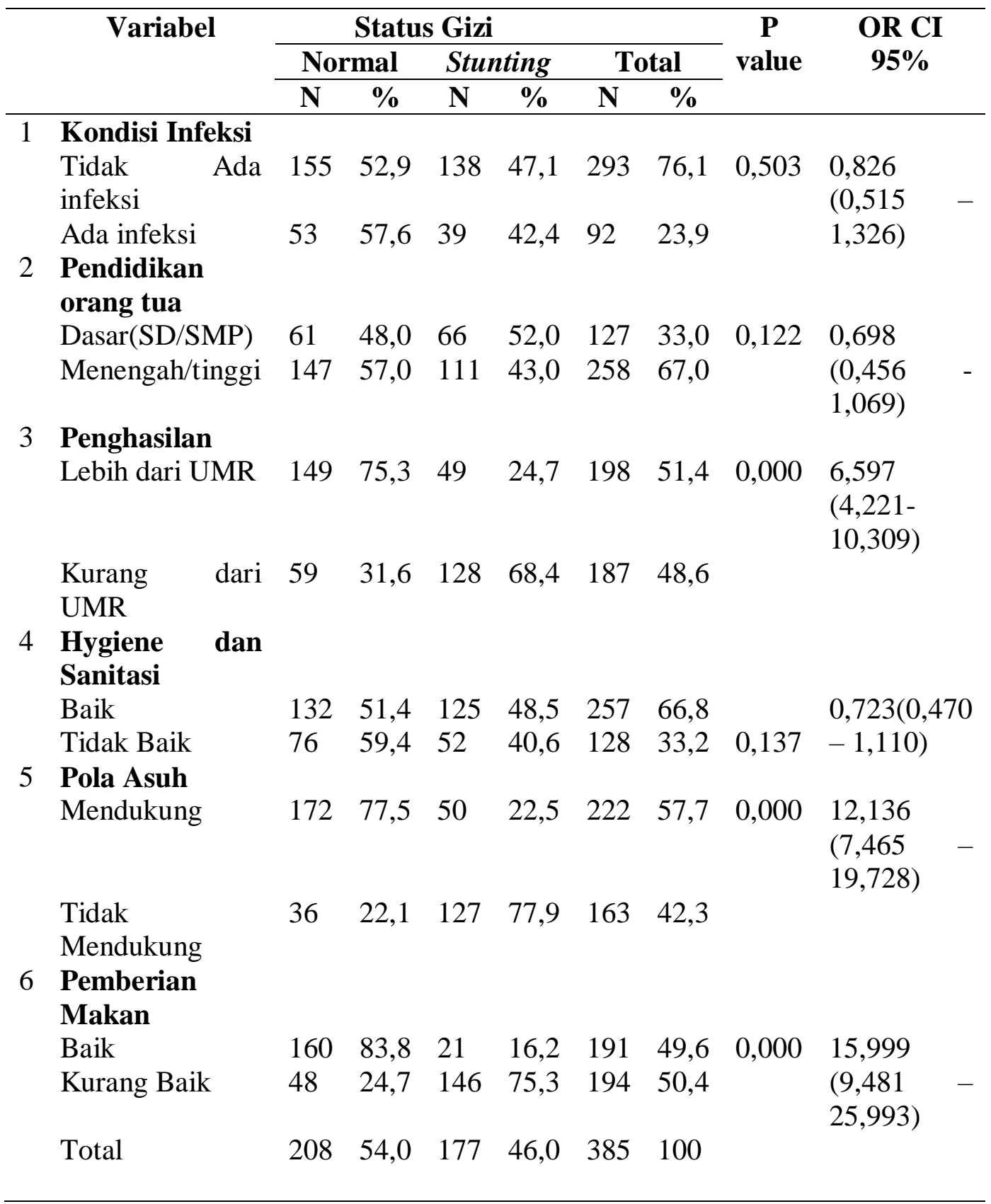

2. Analisis Multivariat 
Analisis mulivariat untuk melihat faktor independen mana yang paling berpengaruh terhadap kejadian stunting. Analisis multivariat dilakukan dengan dimulai dari uji chi square. Faktor risiko dengan $\mathrm{p}$ value $<0,25$ dimasukkan dalam pemodelan multivariat dengan analisis regresi logistik ganda.

\section{Tabel 2 Pemodelan Faktor - Faktor Yang Berhubungan Dengan Kejadian Stunting Pada Balita Di Kabupaten Pesawaran}

\begin{tabular}{|c|c|c|c|c|c|}
\hline Variabel & Koef B & SE (B) & Nilai $p$ & POR*Adj & (IK 95\%) \\
\hline $\begin{array}{c}\text { I. Model Awal dan } \\
\text { Akhir }\end{array}$ & & & & & \\
\hline Penghasilan & 0,635 & 0,332 & 0,056 & 1,888 & $0,985-3,617$ \\
\hline Hygiene dan Sanitasi & $-0,891$ & 0,333 & 0,007 & 0,410 & $0,213-0,788$ \\
\hline Pola Asuh & 2,296 & 0,360 & 0,000 & 9,933 & $4,907-20,105$ \\
\hline Pemberian Makan & 2,894 & 0,330 & 0,000 & 18,074 & $9,467-34,505$ \\
\hline Konstanta & $-2,750$ & 0,321 & 0,000 & 0,064 & \\
\hline
\end{tabular}

Berdasarkan tabel 2 menunjukkan bahwa variabel penghasilan merupakan varibel yang tidak signifikan dari pemodelan, namun demikian variabel ini tidak dapat dihilangkan dari pemodelan karenad dapat merubah nilai OR $>10 \%$ dari pemodelan awal, sehingga penghasilan merupakan faktor confounding pada pemodelan ini. Hasil analisis multivariate didapatkan bahwa pola pemberian makan merupakan faktor yang paling berpengaruh terhadap kejadian stunting pada balita. Berdasarkan hasil uji statistik didapatkan nilai OR 18,074 (95\% CI 9,467 - 34,505) hal ini berarti bahwa orang tua yang tidak melakukan pemberian makan dengan baik berisiko 18,0 kali pada balitanya menderita stunting bia dibandingkan dengan balita yang orang tuanya memiliki pola pemberian makan baik.

\section{PEMBAHASAN}

Menurut WHO, Stunting diklasifikasikan jika nilai $\mathrm{Z}$ tinggi badan untuk usia di lebih dari -2. Balita yang menderita stunting berdampak jangka panjang pada perkembangan kognitif, Prestasi sekolah, produktivitas ekonomi di masa dewasa danreproduksi ibu ${ }^{7}$.

Stunting timbul sebagai akibat dari kekurangan gizi kronis terhadap anak. 
Potensi pertumbuhan terganggu disebabkan oleh efek kronis asupan makanan yang tidak memadai dan kondisi kesehatan yang buruk ${ }^{8}$. Faktor risiko utama untuk stunting pada penelitian ini adalah penghasilan, pola asuh dan pola pemberian makan.Faktor pendidikan, infeksi dan hygine sanitasi tidak berhubungan signifikan pada penelitian ini.

Pada penelitian di Tanzania tahun 2015 faktor stunting dipengaruhi oleh: usia anak, jenis kelamin anak, Tingkat pendidikan ibu, usia ibu saat kelahiran anak, tempat melahirkan, jenis persalinan, IMT ibu dan riwayat menyusui, ekonomi, sumber air minumdan wilayah geografis ${ }^{8}$.

Hasil analisis hubungan antara kondisi infeksi dengan stunting balita di Kabupaten Pesawaran, diperoleh bahwa riwayat infeksi tidak meningkatkan kejadian stunting. Hasil penelitian ini tidak sejalan dengan penelitian Kusumawati tahun 2015 yang menjelaskan bahwa faktor anak yaitu batita yang sering sakit infeksi akan berisiko 8,84 kali untuk menderita stunting 9 .

Hasil penelitian ini sejalan dengan Anisa tahun 2012 bahwa kondisi infeksi tidak berhubungan secara bermakna dengan kejadian stunting. Hasil penelitian ini memang tidak sesuai dengan teori yang sebenarnya yang menjelaskan hubungan infeksi dengan kejadian stunting.Hal ini dapat dijelaskan bahwa penyakit infeksi yang ditanyakan pada kuesioner ini merupakan penyakit infeksi selama satu bulan terakhir yang merupakan infeksi akut. Pada kasus infeksi akut akan berpengaruh kepada berat badan bukan kepada tinggi badan. Oleh sebab itu hal ini yang menyebabkan riwayat infeksi tidak berhubungan dengan status gizi dalam kasus stunting. Stunting sendiri merupakan efek jangka panjang dari konsumsi kronis diet yang dikombinasikan dengan morbiditas, penyakit infeksi dan kondisi lingkungan ${ }^{10}$.

Hasil analisis hubungan antara pendidikan orang tua dengan status gizi balita di Kabupaten Pesawaran, diperoleh pendidikan orang tua tidak meningkatkan kejadian stunting.Pada penelitian ini didapatkan bahwa pendidikan ibu tidak berhubungan dengan kejadian stunting.Namun demikian pada analisis multivariate menjelaskan bahwa pendidikan orang tua bukan menjadi faktor risiko stunting pada balita.

Penelitian ini juga tidak sejalan dengan penelitian Kusumawati tahun 2015 yang menjelaskan bahwa pendidikan berhubungan dengan kejadian stunting pada balita.Hasil penelitian ini tidak sejalan dengan teori bahwa pendidikan orang tua berhubungan dengan kejadian stunting.

Pada penelitian ini menjelaskan bahwa pendidikan orang tua saat ini tidak 
menjamin anak mendapatkan asupan makanan yang benar.Hal ini dapat disebabkan oleh pola asuh anak yang tidak langsung diasuh oleh orang tuanya sehingga pada pemenuhan kebutuhan sehari-hari orang tua tidak dapat langsung memantau balita.Sesuai pada penelitian ini diapatkan bahwa pola asuh orang tua berhubungan signifikan dengan kejadian stunting pada balita.

Hasil analisis hubungan antara penghasilan orang tua dengan status gizi balita di Kabupaten Pesawaran diperoleh bahwa orang tua yang berpenghasilan kurang dari UMR akan mingkatkan kejadian balita stunting sebesar 6,5 kali dibandingkan dengan orang tua dengan penghasilan lebih dari UMR

Penghasilan keluarga merupakan faktor yang mempengaruhi dan menentukan kebutuhan akan kualitas dan kuantitas makanan dengan jumlah dan mutu yang memadai. Penghasilan keluarga dapat dilihat dari besar pendapatan yang berpengaruh terhadap tingkat konsumsi pangan termasuk zat gizi ${ }^{9}$.

Status sosioekonomi yang buruk adalah faktor yang terkait dengan stunting dan stunting parah. Pemodelan memilih itu,

Tingkat pendidikan ibu, pengetahuan ibu Penilaian status gizi anak dan pemberian fasilitas kesehatan adalah prediktor anak stunting.Status kekayaan yang rendah dari keluarga bisa meningkatkan peluang Anakanak dalam keluarga sakit dan akhirnya menjadi stunting ${ }^{11}$.

Hasil penelitian ini sejalan dengan penelitian Oktarina tahun 2013 Balita yang berasal dari keluarga dengan status ekonomi rendah lebih banyak mengalami stunting dibandingkan balita dari keluarga dengan status ekonomi tinggi ${ }^{12}$.

Hasil analisis hubungan antara hygiene dan sanitasi dengan status gizi balita di Kabupaten Pesawaran diperoleh bahwa hygiene dan sanitasi tidak meningkatkan kejadian stunting ${ }^{12}$.

Temuan lain studi ini menunjukkan bahwa balita dari keluarga yang memiliki sumber air minum tidak terlindung lebih banyak mengalami stunting dibandingkan balita dari keluarga yang memiliki sumber air minum terlindung. Studi membuktikan bahwa terdapat hubungan antara sumber air minum dengan kejadian stunting balita.Balita yang ber-asal dari keluarga yang memiliki sumber air minum tidak terlindung 1.35 kali lebih berisiko mengalami stunting dibandingkan dengan balita dari keluarga dengan sumber air minum terlindung.Beberapa penelitian di berbagai negara menunjukkan bahwa kualitas sumber air minum memiliki hubungan positif dengan pengurangan kejadian diare dan kematian pada anak. ${ }^{12}$

Hasil penelitian ini memang tidak sesuai dengan teori yang sebenarnya yang 
menjelaskan hubungan infeksi dengan kejadian stunting.Hal ini dapat dijelaskan bahwa penyakit infeksi yang ditanyakan pada kuesioner ini merupakan penyakit infeksi selama satu bulan terakhir yang merupakan infeksi akut. Pada kasus infeksi akut akan berpengaruh kepada berat badan bukan kepada tinggi badan. Oleh sebab itu hal ini yang menyebabkan riwayat infeksi tidak berhubungan dengan status gizi dalam kasus stunting. Stunting sendiri merupakan efek jangka panjang dari konsumsi kronis diet yang dikombinasikan dengan morbiditas, penyakit infeksi dan kondisi lingkungan ${ }^{10}$.

Hasil analisis hubungan antara pola asuhdengan status gizi balita di Kabupaten Pesawaran diperoleh bahwa orang tua yang memilik pola asuh tidak mendukung akan meningkatkan kejadian balita stunting sebesar 12,1 kali dibandingkan dengan orang tua dengan pola asuh yang mendukung.

Balita dari keluarga dengan jumlah anggota rumah tangga banyak cenderung mengalami stunting dibandingkan balita dari keluarga dengan jumlah anggota rumah tangga cukup. Dapat disimpulkan bahwa terdapat hubungan antara jumlah anggota rumah tangga dengan kejadian stunting pada balita ${ }^{12}$.

Hasil analisis hubungan antara pola pemberian makandengan status gizi balita di Kabupaten Pesawaran diperoleh bahwa pola pemberian makan tidak baik akan meningkatkan kejadian balita stunting sebesar 15,9 kali dibandingkan dengan orang tua yang melakukan pola pemberian makan baik

Makanan yang mengandung protein berguna untuk pertumbuhan bagi bayi sehingga apabila terjadi defisiensi yang kronis dapat menghambat pertumbuhan bagi bayi ${ }^{10}$. Tidak cukupnya pemberian makanan dan perawatan tambahan Anak untuk mempertahankan nutrisi yang cukup untuk pertumbuhan.Alasannya mungkin anak-anak secara bertahap mengadopsi makanan tambahan setelah empat tahun. Perbedaan ini mungkin disebabkan oleh sosial budaya dan variasi makan antara wilayah Somalia dan tempat belajar ${ }^{11}$.

Stunting merupakan refleksi jangka panjang dari kualitas dan kuantitas makanan yang tidak memadai dan sering menderita infeksi selama masa kanakkanak.Anak yang stunting merupakan hasil dari masalah gizi kronis sebagai akibat dari makanan yang tidak berkualitas, ditambah dengan morbiditas, penyakit infeksi, dan masalah lingkungan ${ }^{9}$.

Efek malnutrisi pada proses kognitif juga dilihat dalam kaitannya dengan penurunan nilai tanpa mempengaruhi tingkat perkembangan dan pengaruhnya terhadap laju perkembangan proses kognitif itu sendiri. Para peserta diidentifikasi kekurangan gizi atau diberi 
gizi cukup dalam kelompok usia lima sampai tujuh tahun dan anak berusia delapan sampai sepuluh tahun ${ }^{13}$.

Anak yang mengalami gangguan pertumbuan pada masa bayi akan lebih pendek di usia sekolah dan intelektual yang kurang ${ }^{3}$. Tingkat kognitif rendah dan gangguan pertumbuhan pada balita stunting merupakan faktor-faktor yang dapat menyebabkan kehilangan produktivitas pada saat dewasa. Orang dewasa stunting memiliki tingkat produktivitas kerja rendah serta upah kerja lebih rendah bila dibandingkan dengan orang dewasa yang tidak stunting ${ }^{12}$.

Berdasarkan tabel 4.3 menunjukkan bahwa variabel penghasilan merupakan varibel yang tidak signifikan dari pemodelan, namun demikian variabel ini tidak dapat dihilangkan dari pemodelan karenad dapat merubah nilai OR $>10 \%$ dari pemodelan awal, sehingga penghasilan merupakan faktor confounding pada pemodelan ini. Hasil analisis multivariate didapatkan bahwa pola pemberian makan merupakan faktor yang paling berpengaruh terhadap kejadian stunting pada balita. Berdasarkan hasil uji statistik didapatkan nilai OR 18,074 (95\% CI 9,467 - 34,505) hal ini berarti bahwa orang tua yang tidak melakukan pemberian makan dengan baik berisiko 18,0 kali pada balitanya menderita stunting bia dibandingkan dengan balita yang orang tuanya memiliki pola pemberian makan baik.

Dari pelbagai penelitian tentang stunting dan literature yang ada diketahui bahwa selain infeksi stunting berhubungan juga dengan defisiensi gizi (mikronutrien dan makronutrien). Terdapat beberapa zat gizi yang berkaitan dengan stunting seperti protein, zat besi, zink, kalsium, dan vitamin D, A dan C. Selain itu, faktor hormon, genetik dan rendahnya pengetahuan orangtua dalam pengasuhan, kemiskinan, rendahnya sanitasi lingkungan, rendahnya aksesibilitas pangan pada tingkat keluarga terutama pada keluarga miskin, rendahnya akses keluarga terhadap pelayanan kesehatan dasar, dan masih terjadi disparitas antar provinsi yang perlu mendapat penanganan masalah yang sifatnya spesifik di wilayah rawan. Stunting merupakan indikator yang sensitif untuk sosial ekonomi yang buruk dan predictor untuk morbiditas serta mortilitas jangka panjang 9 .

$$
\text { Menurut Oktarina }
$$

menunjukkan bahwa jumlah anggota rumah tangga merupakan faktor dominan yang berhubungan dengan kejadian stunting pada balita.Di antara faktor sosiodemografi faktor yang paling berisiko tinggi terhadap kejadian stunting adalah besarnya keluarga. Hal ini karena keluarga butuh kemampuan lebih agar dapat menyediakan makan-an dalam jumlah 
banyak untuk anggota keluarga yang banyak.

Salah satu upaya pencegahan kejadian stunting adalah dengan meningkatkan peran aktif ibu dalam kegiatan Posyandu di wilayahnya. Pemeriksaan status gizi berkala dapat mencegah kejadian gangguan gizi kronis yang berdampak pada masa depan anak. Pada penelitian Nasri tahun 2016 menjelaskan bahwa Posyandu memberikan dampak positif terhadap pada balita dan meningkatkan pengetahuan ibu tentang gizi balita ${ }^{14}$.

Keterbatasan pada penelitian ini adalah data pada variabel kondisi infeksi merupakan data yang didapat dari keterangan subjektif ibu dan peneliti tidak mengkonfirmasi langsung pada petugas kesehatan setempat.

\section{SIMPULAN}

Dalam penelitian kami, penghasilan keluarga, pola asuh dan pola pemberian makan berhubungan siginifikan dengan kejadian stunting di Kabupaten Pesawaran Lampung.Upaya untuk meningkatkan pola asuh, dan cara pemberian makan yang benar dengan harga murah dapat diupayakan untuk mencegah kejadian stunting.

\section{DAFTAR PUSTAKA}

1. Kureishy S, Khan Gn, Arrif S, Ashraf K, Cespedes A, Habib Ma, Et Al. A Mixed Methods Study To Assess The Effectiveness Of Food-Based Interventions To Prevent Stunting Among Children Underfive Years In Districts Thatta And Sujawal, Sindh Province, Pakistan: Study Protocol. Bmc Public Health. 2017;17(24):6.

2. Black Re, Allen Lh, Bhutta Za, Caulfield Le, Onis Md, All E. Maternal And Child Undernutrition: Global And Regional Exposures And Health Consequences. The Lancet. 2008;07:14.

3. Zhang Y, Zhou J, Niu F, Donowitz Jr, Haque R, Petri Wr, Et Al. Characterizing Early Child Growth Patterns Of Height-For-Age In An Urban Slum Cohort Of Bangladesh With Functional Principal Component Analysis. Bmc Pediatrics. 2017;17(84):11.

4. Nkurunziza S, Meessen B, Geertruyden Jpv, Korachais C. Determinants Of Stunting And Severe Stunting Among Burundian Children Aged 6-23 Months: Evidence From A National Cross-Sectional Household Survey, 2014 Bmc Pediatrics. 2014;17(176):14.

5. Riskesdas. Riset Kesehatan Dasar. Jakarta: Kementrian Kesehatan Ri, 2013.

6. Vásquez Ah, López At. Chronic Malnutrition Among Children Under Five In Peru: Spatial Analysis Of Nutritional Data, 2010-2016. Rev Esp Salud Publica. 2017;19(91):10.

7. Kinyoki Dk, Berkley Ja, Moloney Gm, Odundo Eo, Kandala Nb, Noor Am. Environmental Predictors Of Stunting Among Children Under-Five In Somalia: Cross-Sectional Studies From 2007 To 2010. Bmc Public Health. 2016;16(654):9.

8. Chirande L, Charwe D, Mbwana H, Victor R, Kimboka S, Issaka Ai, Et Al. Determinants Of Stunting And Severe Stunting Among Under-Fives In Tanzania: Evidence From The 2010 
Cross-Sectional Household Survey.

Bmc Pediatrics. 2015;15(165):13.

9. Kusumawati E, Rahardjo S, Sari Hp. Model Pengendalian Faktor Risiko Stunting Pada Anak Usia Di Bawah Tiga Tahun. Jurnal Kesehatan Masyarakat Nasional. 2015;9(3):8.

10. Anisa P. Faktor-Faktor Yang Berhubungan Dengan Kejadian Stunting Pada Balita 25-60 Bulan Di Kelurahan Kalibaru Depok Tahun 2012. Depok: Universitas Indonesia; 2012.

11. Birhanu A, Mekonen S, Atenafu A, Abebaw, Dwiriani Cm. Stunting And Associated Factors Among Children Aged 6-59 Months In Lasta Woreda, North East Ethiopia, 2015: A Community Based Cross Sectional Study Design. J Fam Med. 2017;4(3):8.

12. Oktarina Z, Sudiarti T. Faktor Risiko Stunting Pada Balita (24-59 Bulan) Di Sumatera. Jurnal Gizi Dan Pangan. 2013;8(3):6.

13. Ross A. Nutrition And Its Effects On Academic Performance How Can Our Schools Improve? Michigan: At Northern Michigan Undersity; 2010.

14. Nazri Cn, Yamazaki C, Kameo S, Herawati Dmd, Sekarwana N, Raksanagara A, Et Al. Factors Influencing Mother's Participation In Posyandu For Improving Nutritional Status Of Children Under-Five In Aceh Utara District, Aceh Province, Indonesia. Bmc Public Health. 2016;16(69):9. 